Section Editor Mitchell S.V. Elkind, MD, MS

Marco Gonzalez-

Castellon, MD

Paloumi Kadakia, MD Joshua Willey, MD, MS Danielle S. Rudich, MD Jeffrey Odel, MD

Correspondence to

Dr. Gonzalez-Castellon: mac2318@columbia.edu

\section{Supplemental data at www.neurology.org}

\title{
Teaching Video NeuroImages: Hollenhorst plaque
}

回

Figure Fundus

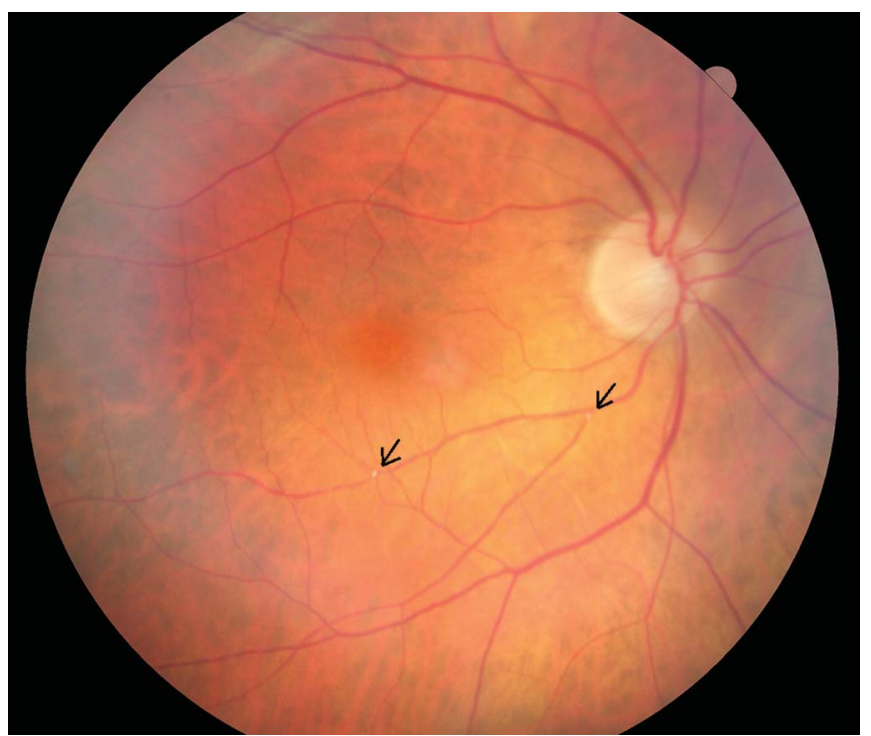

Retinal photograph showing 2 Hollenhorst plaques (arrows).

A 73-year-old man with hypertension and hyperlipidemia was seen in clinic complaining of decreased vision in his right eye. Bedside examination demonstrated a right eye inferior lateral visual field defect due to ischemic optic neuropathy and 2 bright intraluminal yellow plaques located in 2 different arteriolar bifurcations (figure). Carotid ultrasound showed an unstable, mobile, nonocclusive, ulcerated plaque in the right carotid bifurcation (see video on the Neurology ${ }^{\circledR}$ Web site at www.neurology.org). Hollenhorst plaques $^{1}$ are cholesterol crystal emboli thought to originate from the ipsilateral carotid artery bifurcation that, in the absence of amaurosis fugax or stenosis, are not associated with an increased risk of ipsilateral cerebral infarct. ${ }^{2}$

\section{AUTHOR CONTRIBUTIONS}

Dr. Gonzalez-Castellon and Dr. Kadakia: study concept and design, acquisition of data, analysis or interpretation of data, and drafting of the manuscript. Dr. Willey: critical review of the manuscript for important intellectual content and study supervision. Dr. Rudich: study concept and design, acquisition of data, and analysis or interpretation of data. Dr. Odel: critical review of the manuscript for important intellectual content and study supervision.

\section{STUDY FUNDING}

No targeted funding reported.

\section{DISCLOSURE}

M. Gonzalez-Castellon, P. Kadakia, and J. Willey report no disclosures. Dr. Willey is funded by National Institute of Neurological Disorders and Stroke K23 NS 073104. D. Rudich reports no disclosures. J. Odel is a consultant for Bayer. Go to Neurology.org for full disclosures.

\section{REFERENCES}

1. Hollenhorst RW. Significance of bright plaques in the retinal arterioles. JAMA 1961;178:23-29.

2. Dunlap AB, Kosmorsky GS, Kashyap VS. The fate of patients with retinal artery occlusion and Hollenhorst plaque. J Vasc Surg 2007;46:1125-1129. 


\title{
Neurology
}

\author{
Teaching Video NeuroImages: Hollenhorst plaque \\ Marco Gonzalez-Castellon, Paloumi Kadakia, Joshua Willey, et al. \\ Neurology 2013;81;e60 \\ DOI 10.1212/WNL.0b013e3182a2ce2b
}

This information is current as of August 26, 2013

Updated Information \&
Services
Supplementary Material
References
Subspecialty Collections

Subspecialty Collections

Permissions \& Licensing

Reprints including high resolution figures, can be found at: http://n.neurology.org/content/81/9/e60.full

Supplementary material can be found at: http://n.neurology.org/content/suppl/2013/08/25/81.9.e60.DC1

This article cites 2 articles, 0 of which you can access for free at: http://n.neurology.org/content/81/9/e60.full\#ref-list-1

This article, along with others on similar topics, appears in the following collection(s):

All Neuro-ophthalmology

http://n.neurology.org/cgi/collection/all_neuroophthalmology

Retina

http://n.neurology.org/cgi/collection/retina

Information about reproducing this article in parts (figures,tables) or in its entirety can be found online at:

http://www.neurology.org/about/about_the_journal\#permissions

Information about ordering reprints can be found online:

http://n.neurology.org/subscribers/advertise

Neurology ${ }^{\circledR}$ is the official journal of the American Academy of Neurology. Published continuously since 1951, it is now a weekly with 48 issues per year. Copyright () 2013 American Academy of Neurology. All rights reserved. Print ISSN: 0028-3878. Online ISSN: 1526-632X.

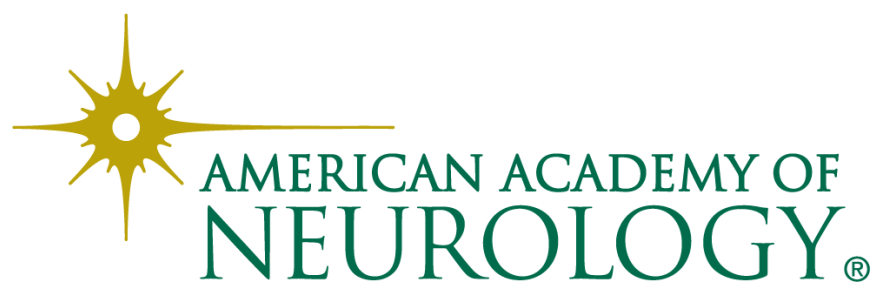

